\title{
O ESPIRITISMO NO CAMPO RELIGIOSO BRASILEIRO
}

\section{THE SPIRITISM IN THE BRAZILIAN RELIGIOUS FIELD}

\author{
Franciso Jomário Pereira ${ }^{1}$
}

\begin{abstract}
Resumo
Neste trabalho buscamos refletir sobre a posição atual do espiritismo no campo religioso brasileiro. Iniciamos com a análise de embates entre o catolicismo e o espiritismo, que se apresenta enquanto reinterpretação da doutrina cristã, perpassando pelas relações entre Estado, sociedade civil e espiritismo. A análise sócio-histórica dessas relações não só expõe as relações entre as duas doutrinas religiosas, mas situa o espiritismo na sociedade brasileira no passado e no presente. Nossos dados se apresentam em forma de discursos datados historicamente e registrados em diversos arquivos, além de entrevistas concedidas por fiéis espíritas que demarcam a posição atual da doutrina. As análises e conclusões se dão a partir da Análise do Discurso de linha francesa. Observamos que o Espiritismo não só tem ganhado terreno entre os fiéis católicos, totalizando mais de 3 milhões de adeptos e 18 milhões de simpatizantes, mas consolidado uma posição política importante e de destaque no campo religioso brasileiro.
\end{abstract}

Palavras-chave: Espiritismo. Campo Religioso Brasileiro. Análise do Discurso.

\begin{abstract}
In this paper we seek to reflect on the current position of spiritism in the Brazilian religious field. We started with the analysis of conflicts between Catholicism and Spiritism, which presents itself as a reinterpretation of Christian doctrine, going through the relations between the State, civil society and Spiritism. The sociohistorical analysis of these relationships not only exposes the relationships between the two religious doctrines, but situates spiritism in Brazilian society in the past and in the present. Our data are presented in the form of speeches dated historically and recorded in several archives, in addition to interviews given by faithful spiritists who demarcate the current position of the doctrine. The analysis and conclusions are based on the French Discourse Analysis. We observe that Spiritism has not only gained ground among the Catholic

\footnotetext{
${ }^{1}$ Professor Doutor em Sociologia pela Universidade Federal da Paraíba, Licenciado, Bacharel, Mestre em Ciências Sociais e especialista em Direitos Humanos pela Universidade Federal de Campina Grande- UFCG. Graduando em História- Cruzeiro do Sul. Professor na educação básica desde 2012, atuando nas disciplinas de Sociologia, Geografia e História. Atua no Ensino Superior e em programas de pós graduação lato sensu nas áreas de Antropologia, Sociologia Geral e da Educação, Metodologia Científica e Métodos e Técnicas de Pesquisa, e em temas como, Religião, Festa, Política, Cultura, Gênero, Sexualidades. Pesquisador no Grupo de Pesquisas Religião, Ruralidades e Movimentos Sociais- RERUMOS- UFCG. Atualmente leciona na Universidade Estadual da Paraíba, e atua como Tutor a distância da Universidade Federal da Paraíba- UFPB.
} 
faithful, totaling more than 3 million adherents and 18 million supporters, but consolidated an important and prominent political position in the Brazilian religious field.

Keywords: Spiritism. Brazilian Religious Field. Discourse Analysis.

\section{INTRODUÇÃO}

O Brasil vive um movimento de transformação no campo religioso, que vai desde o declínio da Religião mais tradicional - no caso, o catolicismo - à estagnação do protestantismo tradicional em relação ao crescimento de diversas igrejas pentecostais e neopentecostais (IBGE, 2010). O Censo Demográfico de 2010 apresenta uma miscelânea de dados em torno de igrejas, religiões e seitas, tendo por finalidade construir um panorama geral sobre as denominações religiosas no Brasil.

Nessa medida, observa-se o crescimento do Espiritismo no Brasil, década após década. No último censo, o de 2010, a população espírita era constituída por 3.848.876 indivíduos; sendo 1.581.701 homens e 2.267.176 mulheres. O censo ainda reforçava a quantidade de simpatizantes, que chega ao número de 18 milhões, ou seja, 10\% da população na época.

A teoria sociológica nos ensina que o processo de institucionalização está diretamente ligado ao processo de conversão e fidelização dos fiéis (PEREIRA, 2020), já que não existe religião sem seguidores ou um corpo especializado, a exemplo do clero católico, pais e mães de santos, e doutrinadores espíritas.

Observamos que um conjunto de características específicas encontradas no espiritismo, tais como o discurso científico, filosófico e religioso, juntamente com os traços do catolicismo brasileiro e demais religiões mediúnicas, aliadas ao trânsito religioso constante, contribuem para o espiritismo ganhar adeptos e fidelizar seus seguidores, ajudando a desenvolver o ethos religioso. Essa é uma das características mais marcantes da doutrina espírita, a bricolagem.

$\mathrm{Na}$ tentativa de compreender como discursos aparentemente antagônicos se articularam para respaldar, dar corpo e fazer prosperar mais uma doutrina "cristã", enveredamos pela Análise do discurso enquanto aporte teórico metodológico, buscando articular e tornar inteligível o processo de formação em solo brasileiro, bem como explicar a posição atual da doutrina espírita.

Muito se discute a respeito do conceito de Análise do Discurso - AD, pois, enquanto metodologia de análise, não se restringe apenas a área linguística. A História, Antropologia e a Sociologia também utilizam a AD como ferramenta analítica. Devemos, dessa forma, explicitar que 
o emprego da $\mathrm{AD}$ não é particularidade do campo linguístico, não é pelo fato de trazer em seu cerne o termo 'discurso' que ficará recluso ao campo das letras, linguística ou da gramática.

\begin{abstract}
A análise do Discurso, tendo o discurso como objeto de investigação, trabalha com a linguagem sob suas diferentes possibilidades de existência, e a considera em uma relação direta com a história- esta como o que determina as possibilidades de realização daquelae com os sujeitos. O discurso é exterior à língua, mas depende dela para sua possibilidade de existência material, ou seja, o discurso materializa-se em forma de texto, de imagens, sob determinações históricas. (FERNANDES, 2012, p. 16).
\end{abstract}

Aqui, nos apoiamos na perspectiva de Michel Foucault (1969, 1970), para pensar, estudar e analisar o discurso, os sujeitos produtores e a reverberação de seus acontecimentos. De forma breve poderíamos afirmar que a $\mathrm{AD}$ é uma forma de analisar a história enquanto produto do discurso, este sob determinas condições políticas, filosóficas e ideológicas.

Por ser usada em diversos campos e áreas, a AD não terá uma definição única, "existem várias, desde orientações mais linguísticas até mais psicossociológicas, e nenhuma pretende ser absolutamente definitiva" (NOGUEIRA, 2001, p. 22). Seria impossível conter todas as variedades teóricas e práticas que podem ser conceituadas por Análise do Discurso. Buscando aprofundar e delimitar melhor uma proposta do conceito de $\mathrm{AD}$, iremos nos ater a Foucault e sua produção, usando como ponto de partida o seu texto em ocasião da Aula Inaugural no Collège de France, em 02 de dezembro de 1970, A Ordem do Discurso.

Escolhemos esse texto ou se preferir momento, por marcar a transição entre dois momentos da produção de Foucault. O primeiro seria o momento arqueológico (As Palavras e as Coisas, 1966, e Arqueologia do Saber, 1969), onde voltou-se para a história da loucura, medicina e dos campos dos saberes - "tratara-se, nesse momento, de investigar os saberes que embasaram a cultura ocidental, de buscar o método arqueológico para entender a história desses saberes" (GREGOLIN, 2006, p. 55). O segundo é A Ordem do Discurso (1970).

$\mathrm{Na}$ primeira fase, ele nos apresenta conceitos importantes que ajudaram a definir a sua perspectiva de $\mathrm{AD}$, como, por exemplo, acontecimento discursivo, enunciado, formação discursiva, que implicaram no conceito de discurso. Este sendo compreendido como,

um conjunto de enunciados, na medida em que se apoiem na mesma formação discursiva; [...] é constituído de um número limitado de enunciados para os quais podemos definir um conjunto de condições de existência; [...] é, de parte a parte, histórico - fragmento de história, unidade e descontinuidade na própria história, que coloca o problema de seus próprios limites, de seus cortes, de suas transformações, dos modos específicos de sua temporalidade, e não de seu surgimento abrupto em meio às cumplicidades do tempo. (FOUCAULT, 2008, p. 133). 
Observamos que, no primeiro momento existe a busca pela ruptura, descontinuidade, transformação, pois Foucault crê que o discurso é prática, ação, não algo estático, contínuo, linear, como se observa na noção tradicional de História. Assim, Foucault nos apresenta uma nova perspectiva e definição, como sendo "um conjunto de regras anônimas, históricas, sempre determinadas no tempo e no espaço, que definiram, em uma dada época e para uma determinada área social, econômica, geográfica ou linguística, as condições de exercício da função enunciativa". (FOUCAULT, 2008, p. 133).

Depois de A Ordem do Discurso de 1970, Foucault percorre outros dois momentos de produção, o segundo, focado nas práticas divergentes, empreende a análise das articulações entre saberes e os poderes, traçando uma genealogia do poder, (Vigiar e Punir, 1975, e Microfísica do Poder, 1979), já em um terceiro momento, "ele investigou a subjetivação a partir de técnicas de si, [...] do governo de si e dos outros, orientando suas pesquisas na direção da sexualidade, da constituição histórica de uma ética e estética de si (História da sexualidade, em três volumes, 1976, 1984, 1984)" (GREGOLIN, 2006 p. 55). Temos que ressaltar que as fases mencionadas não são estanques e separadas, elas se complementam e se reconfiguram.

Pensando a construção teórica da AD por Foucault, nos ateremos a análise dos discursos espíritas, sendo analisados a partir da concepção teórica foucaultiana. Assim, buscamos compreender os efeitos causados pelos discursos contrários ao espiritismo e como tal discurso acaba por posicionar e reposicionar a doutrina no campo religioso brasileiro. Para tal empreitada, apresentaremos, de forma breve, o histórico do surgimento da doutrina, bem como a sua chegada ao Brasil, aprofundando o debate em aspectos contemporâneos da doutrina, buscando posicionála no campo religioso brasileiro.

\section{HISTORICIZANDO O ESPIRITISMO NO BRASIL}

Conforme registros históricos, o surgimento do Espiritismo data do século XIX na França, de modo que fenômenos inexplicáveis começaram a movimentar a Europa. Mesas giratórias e “inteligentes" chamaram atenção do até então Hippolyte Leon Denizard Rivail, que adotaria posteriormente o pseudônimo de Allan Kardec, tornando-se o codificador da doutrina que viria a florescer e a ganhar espaço no Brasil (ARRIBAS, 2017, 2014; GIUMBELLI, 1995).

Lewgoy (2008 p. 85) argumenta que "Allan Kardec, o criador do espiritismo, encarnou como poucos o ideal racionalista do século XIX, quando a ciência, a filosofia da história e o determinismo passaram a tomar o lugar do voluntarismo subjetivo na imaginação moral". O século 
XIX foi o das transformações nas sociabilidades (ORTIZ, 2001), nos modos de produção, fins de impérios e monarquias, mudanças políticas, avanços médicos (anatomia humana), fim da escravidão; sendo, portanto, um século historicamente rico, não poderia deixar de ter marcos no campo religioso.

As obras que inauguram e servem de base moral e espiritual da doutrina Espírita, reunidas de modo a forma um Pentateuco Espírita - O Livro dos Espíritos, O Livro dos Médiuns, O Evangelho Segundo o Espiritismo, O Céu e o Inferno e A Gênesis - foram codificadas por Allan Kardec. Como dito anteriormente, foram influenciadas pelo contexto histórico europeu e francês, adotando e modificando conceitos criados por Swedenborg, Mesme, Hahnemann e Lévi.

No Brasil, a Igreja Católica influenciava fortemente o poder público, atuando como construtora, disseminadora e controladora da verdade religiosa bem como da moral a ser adotada por toda a sociedade; por meio da religião, exercia o controle e coagia os indivíduos a se resignarem em suas condições sociais ${ }^{2}$. Os clérigos eram seres ungidos pelo poder e sabedoria divina; a eles era dado o direito de certificar os discursos como falsos ou verdadeiros, ao passo que interditavam tudo aquilo que lhes fugia da compreensão, negando o direito de construir outras verdades, criando um processo de ocultamento e de controle dos discursos.

A igreja combateu todo e qualquer discurso que fosse contrário aos dogmas que prescrevia e defendia, proibindo, com isso, outras interpretações do cristianismo que não fossem a sua. Desse modo, ao aportar no Brasil, o espiritismo passou a ser visto como a teoria/doutrina "de socialista republicano" que pregavam o fim do catolicismo. Logo, deveria ser combatida, pois não era permitido propagar ideias republicanas e revolucionárias no Brasil Império, muito menos tramar o fim da igreja católica, desde sua chegada, o espiritismo foi combatido, perseguido e desarticulado.

$\mathrm{Na}$ segunda metade do século XIX, ocorreram transformações no catolicismo, em que os embates entre Roma e o Imperador foram motor de transformação para a sociedade brasileira, especialmente no campo religioso. É nesse cenário de mudanças e conflitos na relação do Estado com a Igreja Católica, que chega ao Brasil o espiritismo. De início, não causou especulações, muito menos alarde, o seu acesso era restrito, não existiam traduções do recém-lançado Livro dos Espíritos. Este era lido em francês, o que dificultava o acesso a sua leitura, só ganhando dimensão e inimigos declarados logo após sua tradução e publicação, em partes, em Salvador, por Luís Olímpio Teles de Menezes, em 1865.

2 Devemos ressaltar que não existe controle, ou tentativa de subordinação sem resistência, compreendemos esse fato, mas não iremos nos ater as resistências que existiam para além do espiritismo. 
Profissional liberal, exercendo as funções de professor e jornalista, Teles de Menezes fundou em 1865 o Grupo Familiar de Espiritismo e, no ano seguinte, o primeiro meio de divulgação da doutrina, o Eco d'Além Túmulo, impulsionado pela necessidade de esclarecer e confrontar os ataques sofridos pela Igreja Católica. Começava a ganhar forma e estrutura a doutrina transplantada da França para o Brasil. Não se demorou e o Arcebispo Primaz do Brasil, D. Manoel Joaquim da Silveira lançou nota criticando a publicação e disseminação das ideias revolucionárias e contrárias a fé cristã católica. Destarte,

Nesta Capital publicou-se um pequeno livro com o título - Filosofia Espiritualista - o Espiritismo - cujas perniciosas doutrinas, contra toda a expectação, têm tomado incremento, pondo-se em prática certas superstições perigosas e reprovadas, que estão no domínio público, e no interesse da vossa salvação, amados Filhos, Nós julgamos conveniente dirigir-vos esta Carta Pastoral, para prevenir-vos contra os principais erros que contém esse pequeno livro, e contra as superstições, que as doutrinas nele contidas se estão praticando, como se nos tem informado, e do que já não é possível duvidar. (Carta Pastoral: Premunindo os seus Diocesanos contra os erros perniciosos do Spiritismo. 25 de julho de 1867. Arcebispo da Bahia e Primaz do Brasil, D. Manoel Joaquim da Silveira).

Nesse contexto, há disputas em várias frentes: o catolicismo lutando para permanecer como religião oficial, lutando para conter os avanços da coroa em detrimento do poder que dispunha, bem como a luta contra novas religiões que se inseriam nas camadas letradas, o que de fato gerou incômodo. O espiritismo luta para se instalar, rebatendo as críticas eclesiásticas, e buscando se distanciar das religiões afro, como forma de não ser marginalizado.

Como a religião oficial era a católica e não existia liberdade de culto, as demais religiões eram praticadas de forma familiar, cada célula familiar poderia praticar e se expressar de forma privada. Assim sendo, utilizou-se da estratégia de formação de um grupo literário de estudos espíritas, nada relacionado com religião, ao menos de forma oficial. Sabemos que foi entre profissionais liberais, intelectuais e aristocratas que se desenvolveram as primeiras rodas de conversa e os primeiros debates em torno do espiritismo na corte brasileira, na capital baiana. Nesta época, foi requerida, junto ao Ministério da Justiça, uma solicitação de autorização de funcionamento, por parte de um grupo de interessados em estudar a doutrina espírita, a qual foi negada. Não se admitia a existência de uma doutrina tida como permissiva que renegava o dogma da ressurreição ${ }^{3}$.

3 Na concepção cristã católica, ressureição significa ressurgir para uma vida nova na vida eterna espiritual. Já para os espíritas, morrer ou desencarnar nos permite renascer novamente quantas vezes for preciso, seja no mesmo mundo ou em outros mais evoluídos ou não, tecnologicamente, moralmente e espiritualmente. 
Em 1873, foi concedida a permissão para a constituição da Associação Espírita Brasileira, de cunho científico, no Rio de Janeiro, capital do império, mas o grupo não conseguiu dar forma e consistência ao espiritismo. Primeiro, por não ser possível praticá-la enquanto religião; segundo, em razão das dificuldades em relação ao preconceito que existiu, à época, devido ao fato de ser comparada ao candomblé; terceiro, por diversas correntes serem constituídas, os puros, os científicos, os ocultistas, os místicos ou os religiosos (ARRIBAS, 2011), opondo-se e dificultando um discurso unificado em torno da defesa da doutrina; por fim, a falta de ampla divulgação da doutrina e tradução das obras de Kardec fizeram com quem levasse mais tempo para que esta ganhasse corpo e espaço no império.

Como argumenta Foucault, a constituição de uma disciplina ocorre por procedimentos internos e, no período monárquico, o espiritismo iniciava o seu processo de constituição enquanto disciplina. Não existia quem pudesse controlar como e o que poderia ser dito: existiam várias interpretações; a autoridade da verdade ainda não estava estabelecida em Kardec e seus livros.

O processo de constituição da doutrina, desde Kardec até aqui, século XXI, passa pela necessidade de comprovação e separação de enunciados em falsos e verdadeiros. Observando o que a história espírita conta, percebe-se que Kardec submetia as mensagens recebidas a diversos médiuns e enviava as mesmas perguntas a diferentes lugares do mundo, aguardando as respostas para compará-las, e só assim observar a consistência e frequência de um determinado padrão, para decretar o enunciado como verdadeiro e a resposta obtida como verídica.

O mesmo processo de submissão e confrontação de dados e mensagens ocorreu no Brasil. Destarte, todo o processo de constituição da doutrina em terras brasileiras passa e perpassa por embates, tentativas de ganhar forma, acessando discursos específicos que se confrontam, surgindo, assim, as dissidências e a criação de novos grupos que adotam o discurso que melhor lhe convém ou que consideram mais adequado.

Nesse primeiro momento, há, claramente, a repressão estatal autorizada e justificada pela relação entre Estado e Igreja Católica. É o que Foucault (1996) entende por direito privilegiado ou exclusivo do sujeito que fala. Nesse caso, o sujeito é a Igreja Católica, pois ela detinha o direito exclusivo sobre os assuntos da religião, por mais que estivesse sob a tutela do império. Dessa maneira, para tratar de assuntos não seculares, a palavra final viria sempre da Santa Madre Igreja Católica amparada na lei do padroado.

Essa repressão se tornava mais evidente no caso do espiritismo, em razão de tal doutrina negar um dos principais dogmas do cristianismo: a ressurreição. Com efeito, era preciso restringir 
ainda mais o alcance de tais ideias, já que estas levantavam questionamentos sobre a capacidade explicativa do cristianismo católico, colocando em xeque o dogma cristão católico.

\section{RELAÇÕES NADA REPUBLICANAS}

Os ataques repressivos contra o espiritismo se iniciam no fim do século XIX e se aprofundam no século XX. Esse fato é observável nos debates entre espíritas e católicos, espíritas e médicos, espíritas e Estado e, por fim, ainda mais complexo, entre os próprios espíritas. Não foi um período fácil, especialmente porque, de fato, a doutrina começou a ganhar adeptos e evidência. Devemos ressaltar que, mesmo com o advento da República e o estabelecimento de um Estado laico, a Igreja Católica seguiu influenciando o debate público, bem como outras áreas, como a médica e a jurídica.

Giumbelli (1997), em seu texto Heresia, Doença, Crime on Religião, apresenta a preocupação da classe médica e como o seu discurso retratava o espiritismo no período de 1890 a 1940:

Veremos como [...] o espiritismo torna-se alvo de preocupação para muitos médicos, que a partir de várias instituições e utilizando-se de vários meios vão formular teorias e acusações para explicá-lo e deslegitimá-lo. [...] os argumentos médicos poderão ser encontrados em teses das faculdades de medicina, em debates nas suas entidades profissionais, em laudos médico-legais, em denúncias de funcionários sanitários; assumirão às vezes a forma de "campanhas contra o espiritismo" e serão constantemente encaminhados a autoridades policiais e governamentais; criarão polêmicas com aqueles que assumem sua identidade de espíritas, entre os quais se incluem muitos médicos; finalmente, serão defendidos, reapropriados e reinterpretados por criminalistas, advogados, juízes, jornalistas, padres e pastores interessados pela mesma questão (GIUMBELLI, 1997, p. 33$34)$.

Observamos no discurso que três termos adjetivavam o espiritismo: doença mental, heresia ou charlatanismo. A lógica da doença mental será apropriada pelo discurso médico; a heresia, pelo discurso religioso católico, e o charlatanismo, pelo discurso jurídico. Três frentes de batalha que aparentemente se justificavam, a partir da lógica binária - ciência/credulidade, religião/superstição, adiantado/primitivo, racional/irracional - acabaram convergindo e compartilhando do mesmo "inimigo".

Essa lógica é observável no primeiro código penal brasileiro no período republicano, onde se preserva a primazia católica e se reforça a lógica médica como a única legalmente e cientificamente reconhecida como detentora da cura. A medicina era de influência francesa, tal qual o espiritismo; ambas, cada uma a seu modo, falam de progresso, mas a medicina se encontrava em 
um campo com validade e reconhecimento, conseguindo influenciar não só o processo de urbanização, costumes morais e políticos, como também o código penal em questão.

Com isso, destaca-se o confronto de discursos, ou melhor, a disputa entre dois campos, um com validade e reconhecimento - a medicina, a qual foi difundida no Brasil sob a conceituação da saúde pública que se instalava enquanto disciplina - e o espiritismo, enquanto religião e ciência positivista. Nesse contexto se insere o discurso jurídico, buscando litigar e resolver as dúvidas:

Código penal: Dos crimes contra a saúde pública

Art. 156. Exercer a medicina em qualquer dos seus ramos, a arte dentaria ou a pharmacia; praticar a homeopathia, a dosimetria, o hypnotismo ou magnetismo animal, sem estar habilitado segundo as leis e regulamentos: Penas - de prisão cellular por um a seis mezes e multa de $100 \$$ a $500 \$ 000$.

O código penal foi influenciado por médicos e religiosos. Assim, espíritas ou a religião espírita não poderia falar em cura, saúde, medicação, pois tais ações discursivas e práticas fazem parte do campo da saúde, da medicina, mesmo que entre os adeptos do espiritismo houvessem médicos, o espiritismo se insere numa disputa antiga entre a alopatia e a homeopatia.

O catolicismo também influenciou a redação do código penal, de modo que se cria uma categoria: o baixo espiritismo, servindo para classificar, criminalizar e perseguir o Candomblé:

Art. 157. Praticar o espiritismo, a magia e seus sortilegios, usar de talismans e cartomancias para despertar sentimentos de odio ou amor, inculcar cura de molestias curaveis ou incuraveis, emfim, para fascinar e subjugar a credulidade publica: Penas - de prisão cellular por um a seis mezes e multa de $100 \$$ a $500 \$ 000$. Art. 158. Ministrar, ou simplesmente prescrever, como meio curativo para uso interno ou externo, e sob qualquer fórma preparada, substancia de qualquer dos reinos da natureza, fazendo, ou exercendo assim, o officio do denominado curandeiro: Penas - de prisão cellular por um a seis mezes e multa de $100 \$$ a 500\$000. (CÓGIGO PENAL, 1890).

Ao mesmo tempo em que impunha limites ao kardecismo, ditando o que ele poderia ou não ser. Ocorria a delimitação via discurso e prática social, imposta juridicamente e aceita socialmente.

A busca por distinção e ratificação da verdade existente não ocorreu apenas por parte de médicos e padres. A distinção entre o espiritismo de mesa branca ou o kardecista em relação ao baixo espiritismo (Candomblé) existiu e persiste até os dias atuais, mesmo que não tenha partido, ao menos de início, de forma espontânea, por parte da primeira.

Dessa forma, se construíram limites externos ao espiritismo, fosse por parte do Estado burocrático, supostamente laico, ou pela Igreja Católica, que se via ameaçada com a constituição de cultos que repensavam e reatualizavam seus dogmas, mas que, até então, não colocavam em 
risco sua hegemonia entre os mais letrados. Porém, observava-se uma maior influência entre as camadas menos favorecidas, que, em momentos de necessidade, acorriam em busca de soluções advindas do "oculto".

A sociedade estava mudando, e o espiritismo acompanhava esse processo de transformação. A estruturação da doutrina espírita pode ser analisada e pensada a partir da concepção foucaultiana de poder. Nos jogos existentes pelo controle do religioso e social, ganhou corpo uma religião que usou uma estratégia que aparentava ser simples, mas se mostrou extremamente complexa, a adoção e a união de discursos que sempre foram vistos como antagônicos, como o religioso, o filosófico e o científico, buscando instituir uma nova verdade sobre a vida após a morte. Com efeito,

Kardec assim se expressa: "O Espiritismo é, ao mesmo tempo, uma ciência de observação e uma doutrina filosófica. Como ciência prática, ele consiste nas relações que se estabelecem entre nós e os Espíritos; como filosofia, compreende todas as consequências morais que dimanam dessas mesmas relações. Podemos defini-lo assim: O Espiritismo é a ciência que trata da natureza, origem e destino dos Espíritos, bem como de suas relações com o mundo corporal" (KARDEC, s/d. Preâmbulo).

Percebe-se que o espiritismo se apropria de certas características do cristianismo, tomando os evangelhos como fonte doutrinária, porém estes são interpretados à luz da doutrina espírita. $\mathrm{O}$ espiritismo se insere em um campo de disputas muito amplo; não rivaliza apenas com a vontade de verdade (FOUCAULT, 1996, 2001) da religião católica, mas também com os homens da ciência, que já rivalizavam com as outras religiões.

No caso da doutrina espírita, torna-se ainda mais curiosa e complexa essa disputa, já que tal doutrina une ou tenta unir duas verdades que se mostram antagônicas: a ciência e a religião, a razão e a fé. São duas verdades que se configuram e reconfiguram, dependendo das contingências históricas. Essas verdades irão influenciar e acarretar cisões entre os fiéis espíritas, provocando a criação de correntes doutrinárias, que influenciaram no processo de estruturação e consolidação do espiritismo no Brasil.

\section{QUESTÕES A RESPEITO DO CAMPO RELIGIOSO BRASILEIRO}

A partir do panorama da formação e condições atuais do espiritismo brasileiro, podemos afirmar que é observado um reposicionamento no campo religioso brasileiro, onde se destaca a

4 Uma lógica semelhante pode ser observada a partir do neopentecostalismo. 
transformação do catolicismo, que passa por um declínio, e crescimento de religiões cristãs, entre elas o espiritismo. As mudanças ocorridas nesse novo campo religioso, ocorrem mediante o trânsito religioso (PEREIRA, 2020), que se observam entre os fiéis cristãos que se deslocam da igreja católica para o protestantismo, neopentecostal, espiritismo, sem esquecer dos que se dizem ou identificam como sem religião.

Carvalho (1999, p.2) assevera que "podemos afirmar que essa variedade de movimentos, igrejas, seitas, cultos e grupos religiosos apresentam graus distintos de inserção na sociedade nacional, resultante de vários condicionamentos históricos e sociais", que no nosso entender, mudam conforme o período histórico e as determinadas condições políticas, econômicas e culturais.

Assim, pode-se afirmar que, de certo modo, existiu um fluxo distinto no desenvolvimento cultural-religioso e não um desaparecimento da religião ao surgir um Estado laico. A laicidade do Estado Brasileiro contribuiu para o surgimento e crescimento de novas religiões, entre elas, o espiritismo, porém dificultou o processo de institucionalização; basta observar o trânsito religioso (ALVES FERNANDES, 2013).

Carvalho exemplifica, ao explicar o dia a dia de uma pessoa ordinária, como é fácil, ao menos observando de longe, a transição que se faz de uma religião ou de um centro ${ }^{5}$ para outro:

Para dar um exemplo, o típico morador do Plano Piloto, centro do projeto modernista do Distrito Federal, quer pratique ou não alguma religião cristã, pode frequentar ocasionalmente feiras místicas, palestras em centros esotéricos e de Nova Era, experimentar com uma gama variada de métodos de meditação, manipulação de forças e energias espirituais. E no momento em que passar por uma crise mais séria em seu estado de saúde ou em suas relações interpessoais seja no trabalho, seja na vida amorosa - pode ir a algum "centro" em busca de apoio espiritual (CARVALHO, 1999, p.3).

O que de fato torna interessante essa transição de uma religião para a outra é uma suposta facilidade de como isso ocorre, como se passasse da sala para o quarto. Mas, podemos nos questionar, até que ponto o ethos religioso se fixa e permanece, com toda fluidez do "fiel", no campo religioso? Cremos que o ponto forte do trânsito religioso seja a formação de uma religiosidade individualista, por isso podemos observar a existência do ethos católico entre os praticantes do espiritismo brasileiro, tendo em vista que ocorre uma agregação e talvez sobreposição na constituição da individualização religiosa.

5 Centro, para Carvalho, não é só o espaço físico onde ocorrem as reuniões, cultos ou missas, mas, sim, o centro do indivíduo, como ele desloca os possíveis centros religiosos, psicológicos que nele coexistem e como se executa a dualidade religiosa. 
Já Pierre Sanchis (1997), chama-nos a atenção para o pluralismo religioso que vivenciamos nas últimas décadas. $\mathrm{O}$ autor aposta que vivemos um momento espiritualista em nosso campo religioso, independente de qual religião seja adepto. Ele nos levar a refletir que o fato de não se declarar ou se identificar com uma única religião não abre espaço para o fim das mesmas, mas sim para uma coexistência, já que o indivíduo é capaz de transitar entre duas ou mais religiões sem ser necessária a sua fidelidade. Devemos lembrar que essa participação não é ilimitada, existem doutrinas que são antagônicas, o que pode impossibilitar o trânsito de um determinado fiel.

Considerando os números dos últimos censos no Brasil, Pierucci e Mariano (2010) refletem sobre o avanço dos "sem religião". Eles afirmam que, em termos demográficos, esse grupo representava menos de 1\% dos brasileiros em 1970, crescendo em 1980 para 4,7\%, e atingindo 7,3\% ou 12.492.403 milhões de brasileiros em 2000, sendo que no último censo de 2010 os dados revelam um crescimento para 15,3 milhões, ou seja, $8 \%$ da população geral ${ }^{6}$.

Os autores afirmam que esse número é crescente entre os indivíduos com escolaridade superior e pós-graduação, mas não deixam de relatar que cresce também entre "adolescentes e jovens adultos do sexo masculino, principalmente com baixo nível socioeconômico" (PIERUCCI \& MARIANO, 2010, p. 286). Esse é um dado interessante para se refletir, pois o aumento dos evangélicos pentecostais tem se dado na camada social mais periférica; entre os espíritas, observase um perfil semelhante ao dos sem religião. Dessa forma,

Se aumentam os "sem religião", é óbvio que estão diminuindo os "com religião". Essa obviedade aponta para o fato de que, no contexto de uma oferta religiosa mais diversificada, nosso país assiste à constituição de um contingente cada vez mais numeroso de cidadãos "alheios" a qualquer confissão religiosa, "desfiliados" de toda institucionalidade religiosa, "desligados" de toda autoridade religiosamente constituída e exercida. Se aumentam os sem religião, quem perde seguidores é o conjunto das religiões institucionalizadas, e isso quer dizer que as organizações religiosas têm hoje menos controle sobre os usos pessoais que os indivíduos fazem dos recursos culturais a seu alcance, mesmo os de natureza religiosa (PIERUCCI \& MARIANO, 2010, p. 287).

Faz-se necessário refletir que a não filiação religiosa não significa o afastamento das religiões, mas talvez seja um trânsito entre duas ou mais. A perda de fiéis católicos, aliado a um crescimento dos sem religião, como apontado acima, talvez tenha proporcionado um clima de desencantamento/racionalização e fim da religião. Porém, vale lembrar que a não

6 Não se inclui nesse total os Ateus, Agnósticos, não determinada e múltiplo pertencimento (religiosidade não determinada/mal definida ou Declaração de múltipla religiosidade). 
institucionalização religiosa não significa ateísmo - 615 mil, cerca de 0.32\%, (IBGE, 2010). Com isso,

Provavelmente temos aqui um dos motivos pelos quais o campo religioso é hoje, cada vez menos, o campo das religiões, pois o homem religioso, na sua ânsia de compor um universo-para-si, sem dúvida cheio de sentido, mas de sentido-parasi, tende a não se sujeitar às definições que as instituições lhe propõem dos elementos de sua própria experiência (SANCHIS, 1997, p. 35).

Dessa forma, Sanchis (1997) argumenta que o trânsito religioso é algo comum no campo religioso brasileiro. Essa perspectiva sempre existiu, mas hoje, devido a um contexto sociopolítico, os indivíduos não são obrigados a escolher e a se identificarem com uma única instituição religiosa ou, até mesmo, com uma única fé.

Diante disso, não estar vinculado a uma instituição, não quer dizer necessariamente que não se acredita em algo ou que não siga alguma doutrina religiosa fora da instituição, se é que é possível. Meslin (2014) defende que o processo de individualização e privatização da experiência religiosa é fator determinante da realidade moderna. Assim se encontra o campo religioso brasileiro, em constante mudança, especialmente com um crescente número de indivíduos que não se definem como seguidores de uma única religião, individualizando a sua religiosidade, intensificando o trânsito religioso.

Qual a posição e situação do espiritismo nesse campo complexo e mutante?

\section{O ESPIRITISMO HOJE NO BRASIL}

Aqui no Brasil tudo é muito religioso, né? (Simão7).

Percebe-se que, mesmo depois de décadas buscando se definir enquanto doutrina, religião, ciência e filosofia, o espiritismo continua se misturando e conversando com as demais religiões, em um processo que, aparentemente, não para ou não vai parar por enquanto. Contudo, o que podemos afirmar a respeito do formato atual, é que ele foi fruto de embates externos e internos, não só com o Catolicismo, ou com a medicina e o sistema jurídico representados pelo Estado, mas com as religiões de matriz afro-ameríndias que aqui existem. Desse modo, o que nos resta é questionar: qual o formato atual, aspectos e características particulares? Já que nos encontramos em um processo de individualização da religião (HERVIEU-LÉGER, 2008).

7 Entrevista concedida por Simão. Entrevista I. [fev. 2019]. Entrevistador: XXXXXXXXXXXXXXX. Acervo pessoal. Campina Grande, 2019. 1 arquivo .mp3 (120 min.) 
Ao ser transladado para o Brasil, o espiritismo foi reconfigurado (LEWGOY, 2008), como anteriormente afirmado. Aparenta ter passado pelo mesmo processo pelo qual passou o Catolicismo ao se tornar distante de Roma (PEREIRA, 2020), onde ocorreu um hibridismo/bricolagem e a influência dos negros e dos índios.

Kardec, que criou uma religião altamente relacionada com os ideais de sua época: a laicidade, o progresso e o espírito científico [...] Nesse sentido, o espiritismo anunciava-se como uma religião natural, o que originou uma tensa e não resolvida relação entre demonstração experimental e revelação, que significa que seu prestígio era dependente da simpatia da comunidade intelectual pelo fenômeno (LEWGOY, 2008, p. 86, grifos nossos).

O espiritismo seguiu por um viés diferenciado do pensado por Kardec, que o idealizou influenciado pelo pensamento da época, século XIX, que era regido pela laicidade, o progresso e o espírito científico. O espiritismo surgiu com a missão de unir três campos, aparentemente opostos, a Religião, a Filosofia e a Ciência. Podemos afirmar que o processo foi realizado com sucesso, tendo em vista não apenas os adeptos, mas a capacidade de transplante para outros países. Em especial, no caso brasileiro, o crescimento da doutrina ocorreu após as adaptações realizadas onde percebe-se substancial mudança:

No caso brasileiro, houve dois deslocamentos importantes em relação ao cientificismo kardequiano: o deslocamento da ênfase na mensagem para a ênfase no carisma do médium e o deslocamento da comunicação espírita em três indivíduos desconhecidos num mesmo espaço mediúnico impessoal para a mediação relacional entre seres já ligados por nexos anteriores, geralmente familiares. Comparando a inserção do espiritismo nas histórias francesa e brasileira Aubrée e Laplantine (1990) mostraram que, comparada à França do século XIX, na sessão espírita no Brasil do século XX predominou um espaço familiar antes que um espaço impessoal. Por isso, as mães e mulheres, figuras centrais na mediação familiar, são tão importantes no desenrolar das sessões (LEWGOY, 2008, p. 86).

O formato adotado se deve, em grande medida, ao seu enxerto nos lares católicos; não o catolicismo romano, mas o catolicismo popular brasileiro, uma derivação do romano. Com isso, pode-se afirmar que o modo de ser espírita tem fortes influências do catolicismo brasileiro. Quem relata esse fato é Simão, 42 anos, professor na área das linguagens, negro, ex-católico, pai e avô; ele está há 25 anos no espiritismo. No trecho a seguir, Simão fala sobre a sua experiência na doutrina em questão:

Mas aí um dia me convenceram a ir, e eu fui; achei interessante, porque eu vi só aquela coisa que eu já gostava no... no... na igreja católica, naquela coisa de... de... 
que engraçado, espírita fala que não tem ritual, mas é meio ritualístico. Toda religião é ritualística. Não tem como você tirar a essência de ritual, a gente procura fazer tudo o mais simples possível, mas tem uma sequência, prece inicial... aí tem os cantos... tinha a pregação, aí tinha a prece final. [...] A alma brasileira ela é muito ritualística e muito religiosa. A religiosidade acho que tá muito entranhado, sabe? E aí, as pessoas tem essa coisa, então, o espiritismo aqui no Brasil... você vê, tem espiritismo em faculdades dos Estados Unidos, cara, que eles fazem pesquisas assim fantásticas sobre mediunidade, sobre... é...transmissão de pensamento..., sabe? Sobre coisas bem interessantes e, cientificamente falando, sem o caráter religioso.

Verificamos que nosso entrevistado faz associações entre as duas religiões, mas consegue distinguir o cerne da religião que prática. Ele nos leva a observar mais a fundo as semelhanças encontradas entre o catolicismo e o espiritismo, levando a crer que o trânsito religioso entre as duas possa ser vivenciado de modo mais tranquilo já que ambas as religiões se baseiam no cristianismo. Para além disso, o trânsito religioso tem se tornado mais frequente, sendo, talvez, fruto da individualização da religião (PEREIRA, 2020).

O mercado existente no campo religioso brasileiro é vasto, temos diversas vertentes dentro de uma mesma corrente religiosa, basta observar o protestantismo neopentecostal ou pentecostal, bem como o Candomblé, Umbanda, Jurema e etc. Quando se fala em espiritismo, sempre existe um questionamento, a qual vertente o Centro Espírita se filia, dentro da doutrina espírita existem diversas práticas e ações que não são comuns a todos, muito menos endossadas pela Federação Espírita Brasileira. Sandra Jaqueline Stoll nos faz refletir sobre essas correntes, ela nos apresenta uma análise a partir das ideias do médium e doutrinador Luiz Gaspareto e o seu espiritismo:

Segundo o médium, esses temas (sexo e dinheiro) constituem até hoje um tabu no Brasil, o que, segundo ele, não ocorre no exterior: "Quando viajo para o estrangeiro e converso com os médiuns, os espíritos conversam abertamente de sexo e seus problemas. Aqui não. No Brasil nenhum espírito toca nesse assunto [...] Aqui só dizem: 'vai tomar passe, vai tomar passe!..."'. Donde conclui: "Apesar dos espíritos terem tentado passar uma mensagem libertadora, aqui os médiuns eram católicos e a linguagem que usaram era própria de sua estrutura mental. Passou o que foi possível. O resto ficou cheio de catolicismo". (STOLL, 2005, p. 180).

Stoll nos leva a refletir a partir das reflexões levantadas pelo médium Gaspareto que expressa e corrobora com a lógica de que, a corrente majoritária na doutrina espírita é representada pela parte religiosa e social, bem parecida com o que se observa no catolicismo brasileiro. Observamos essa realidade na fala de Pedro: 
Pedro8: A doutrina ele é muito, ela é de ação. É isso que eu entendo que a doutrina passa. De você agir no bem, de você trabalhar no bem, trabalhar o evangelho, na caridade, na assistência... aos outros Um dos pontos. Um dos pontos dela é essa. Assistencialismo seja ele o físico ou espiritual. O físico pela assistência em comunidades carentes.

Observamos que foram relegados a um segundo plano o trabalho mediúnico e de formação de novos médiuns. Bem como deixando de lado o debate sobre sexo, sexualidade (PEREIRA, 2020), prosperidade e autoajuda (STOLL, 2005), todo e qualquer debate que possa ser controverso. Por esses motivos, Luiz Gaspareto e sua família abriram dissidência e se inclinaram para um novo ramo: o espiritismo exotérico.

As movimentações no campo religioso são constantes, é algo que decorre das transformações ocorridas nas religiões internamente.

Encontramos, nesse movimento, diversas formas de espiritismo: um espiritismo tipo orientalista, meio esotérico, meio ocultista, partidário, dentre outras, da noção de chacras e da ideia de karma; encontramos também um espiritismo estilo New Age, com técnicas de cromoterapia, apometria e ufologia; um espiritismo, digamos, mais brasileiro, mesclado com caboclos, índios e pretos velhos, um espiritismo mais científico, que lida, por exemplo, com pesquisas e experiências de quase-morte (EQM) e com a parapsicologia; vemos também um espiritismo filosófico interexistencialista, que associa as leituras de Allan Kardec de grandes filósofos e pensadores, e assim por diante (ARRIBAS, 2014, p. 45).

As correntes existentes e que por vezes são antagônicas, acabam sendo congregadas e disciplinadas, até certo ponto, pelo tripé Religião, Filosofia e Ciência. No final do dia, sempre se buscará a justificativa em Kardec. Mesmo quando o lado científico tenha sido deixado de lado e apenas resgatado quando se recorre ao discurso de autoridade, assegurando um lugar qualificado e de prestígio social.

O Espiritismo é ao mesmo tempo, uma ciência de observação e uma doutrina filosófica. Como ciência prática ele consiste nas relações que se estabelecem entre nós e os espíritos; como filosofia, compreende todas as consequências morais que dimanam dessas mesmas relações (KARDEC, 2013. p. 40).

Os doutrinadores espíritas recorrem a uma metodologia herdada e reconfigurada da ciência positivista, que as demais não fazem uso, acreditada como cientifica e incorporada no processo de contato com o mundo espiritual. Assim, é construída e instituída uma ciência espírita, onde seus adeptos devem buscar centros especializados para estudar, aperfeiçoando a moralidade, caridade e

8 Entrevista concedida por Pedro. Entrevista I. [fev. 2019]. Entrevistador: XXXXXXXXXXXXXXX. Acervo pessoal. Campina Grande, 2019. 1 arquivo .mp3 (120 min.) 
a mediunidade, somente assim poderão ser de fato espíritas. Institui-se, assim, o controle sobre os adeptos e sobre a verdade instituída sobre a doutrina. Foi contra essa centralidade, controle e direcionamento para as questões religiosas e sociais que os Gasparetos se tornaram dissidentes, buscavam formas de ampliar o acesso ao mercado religioso, bem como ao público sedento de inovações, mas sem abrir mão das crenças firmadas pelo ethos incorporado ao longo de uma vida.

Um elemento característico da constituição de um sistema religioso é a impossibilidade de um começo absolutamente novo: não existe renovação religiosa total. Uma nova religião pode formar-se a partir de alguns dogmas novos opostos aos anteriores, mas a referência às religiões precedentes é, de todas as formas, inevitável (ARRIBAS, 2014, p. 08).

Arribas nos ajuda a compreender a lógica externada por Simão

Simão: Toda religião é ritualística. Não tem como você tirar a essência de ritual. A gente procura fazer tudo o mais simples possível, mas tem uma sequência, prece inicial... aí, tem os cantos... tinha a pregação, aí, tinha a prece final. Eu senti que a minha transição pra... do catolicismo pra igreja... pra o espiritismo, ele se deu meio que... que por associação, sabe? Por exemplo, eu substitui tudo assim... a figura do padre passou a ser a figura do pregador espírita; aquele momento da eucaristia, da constrição, passou a ser o momento em que você toma o passe... então...rsrssrs era tudo por associação. Era uma associação pra mim. Porque, assim, eu ainda continuava mútuo. É tanto que, durante muito tempo, eu ainda fiquei assim, eu ia lá no espiritismo e vinha aqui na igreja, sabe? Eu dialogava muito com isso. É... já agora há uns dez anos atrás, muito tempo depois, minha família virou toda evangélica.

O processo de conversão ou adesão total ou parcial a doutrina pode ocorrer por associação, assim como apresentado por Simão. Há uma pluralidade de formas de se viver uma mesma religião, de modo que é incalculável devido à subjetividade envolvida. Basta observar as diversas Igrejas protestantes, evangélicas, pentecostais ou neopentecostais. Da mesma forma, são os centros espíritas: eles não são iguais, mas oferecem estrutura semelhante, divergindo na execução de suas atividades. Assim, o que se encontra em um pode ser diferente em outro; os produtos e serviços são diversificados, mesmo existindo diretrizes da FEB que buscam homogeneizar os procedimentos oferecidos pelas instituições filiadas à federação.

Essa digressão a respeito da compreensão do conceito e do processo de conversão se faz necessária para observamos que o espiritismo não conseguiu se isolar das demais religiões, tendo em vista que o ethos religioso persiste e somente com o tempo é reconfigurado, podendo gerar uma individualização da religião adotada, não sendo necessário abrir mão de todas as expressões e símbolos religiosos anteriores. Isso coloca não só o espiritismo em constante comunicação com as demais religiões, mas o campo religioso todo se comunica, se reconfigura e se move diuturnamente. 


\section{CONSIDERAÇÕES}

Inicialmente podemos observar e afirmar que os discursos externos proferidos pelos "rivais" do espiritismo, a classe médica, juristas e os católicos, reprimiram o seu desenvolvimento e expansão até a constituição de uma federação capaz de organizar as diretrizes da doutrina espíritas. Esse processo ajudou a expandir e organizar os centros e suas atividades. Foi um processo conturbado, mas que resultou na aquisição do status de religião para a doutrina espírita, entre seus pares e críticos.

Segundo, a partir das análises traçadas, observamos que o espiritismo é uma religião que tem se destacado no campo religioso brasileiro, especialmente por agregar em sua doutrina discursos que são tidos como divergentes. Essa lógica é destacada por Giumbelli (1997) para quem o espiritismo seria "o resultado do confronto entre lógicas diferenciadas e heterogêneas, sob as quais se revelam 'sistemas de crenças' cuja especificidade se produz entre discordâncias, desencontros e disputas em torno de questões absolutamente fundamentais" (1997, p. 35). Ocorrendo a ressignificação e uma retradução por parte dos doutrinadores, que conseguem vender aos fiéis e simpatizantes uma nova concepção do cristianismo.

Terceiro, observamos que o crescimento do Espiritismo no Brasil tem relação direta com a entrada e revisitação de tradições esotéricas e religiosas tradicionais, proporcionando uma hipotética capacidade maior de se aceitar um público mais diversificado e frequentadores sem lhes cobrar fidelidade; ao menos, aparentemente.

Quarto, no Brasil observa-se um espiritismo diferenciado do francês, mesmo recorrendo à fórmula ciência, religião e filosofia, os centros, ao menos a maioria ligada à FEB, estão direcionados para a prática religiosa e assistencial, deixando de lado a ciência (PEREIRA, 2020). O espiritismo brasileiro ainda se distância das demais religiões de possessão, especificamente na metodologia adotada para o contato com os desencarnados, além das personagens e figuras que mantém contato (MOUTINHO, 2005) sendo estas divididas em tipos, as instruídas que oferecem informações, orientações, tratamentos espirituais, servem de mentores espirituais dos centros, nesse grupo temos Emmanuel, André Luis, Bezerra de Menezes, entre outros. O segundo tipo é aquele que vem em busca de auxílio espiritual para poderem deixar de sofrer, buscam libertação desse mundo, são os espíritos em sofrimento, ou, como costumamos dizer, "almas penadas".

Por fim, o campo religioso brasileiro vive um momento de transformações profundas, especialmente pelo fato de o fiel conseguir transitar entre as mais diversas religiões sem se sentir 
obrigado a escolher apenas uma. Esse trânsito religioso permite a constituição de expressões religiões únicas e individuais, algo merecedor de um debate mais profundo. Mas aqui, podemos afirmar que o espiritismo enquanto religião institucionalizada segue se desenvolvendo e acessando um público cada vez maior e mais diverso, garantindo espaço e status no atual campo religioso brasileiro.

\section{REFERÊNCIAS BIBLIOGRÁFICAS}

ALVES FERNANDES, Silvia Regina. Os números de católicos no Brasil- Mobilidade, experimentação e propostas não redutivistas na análise do Censo. In: TEIXEIRA, Faustino, MENEZES, Renata. Religiões em Movimento: o Censo de 2010. Petrópolis: Editora Vozes, 2013. Pp 111-160.

AMORIM, P. P. "ROUSTAING: A CISÃO NO INTERIOR DA FEDERAÇÃO ESPÍRITA BRASILEIRA (1920 - 1922).” Revista Brasileira de História das Religiões. Maringá (PR) v. III, n.9, jan/2011. ISSN 1983-2859

AMORIM, P. P. Muito além da unidade: a cisão no movimento espírita. In: AMORIM. (Org.). Muito além da unidade: a cisão no movimento espírita. 1ed.São Paulo: UNESP, 2012, v. p. 119138.

ARRIBAS, Célia da Graça. Autoridades espíritas: critérios para tipologias e repartições das lideranças no espiritismo. In: SOUZA, André Ricardo de. Etal (org) Espiritualidade e espiritismo: Reflexões para além da religiosidade. Porto de Ideias. São Paulo. 2017.

ARRIBAS, Célia da Graça. Uma sociologia histórica do espiritismo. Anais do III encontro nacional do gt história das religiões e das religiosidades - anpuh -Questões teóricometodológicas no estudo das religiões e religiosidades. IN: Revista Brasileira de História das Religiões. Maringá (PR) v. III, n.9, jan/2011. ISSN 1983-2859. Disponível em < http://periodicos.uem.br/ojs/index.php/RbhrAnpuh/article/view/23641 > Acessado em 10 de dezembro de 2018.

ARRIBAS, Célia da Graça. No Princípio Era Verbo. Espíritas e Espiritismos na Modernidade Religiosa Brasileira. Tese de Doutorado em Sociologia no Programa de Pós Graduação em Sociologia da Universidade De São Paulo. São Paulo. 2014.

BRASIL. Instituto Brasileiro de Geografia e Estatística. Censo Demográfico e Populacional Brasileiro de 2010.

CARVALHO, José Jorge de. UM ESPAÇO PÚBLICO ENCANTADO. PLURALIDADE RELIGIOSA E MODERNIDADE NO BRASIL. SÉRIE ANTROPOLOGIA No 29, Brasília 1999. 
FOUCUALT, Michel. A arqueologia do saber. Tradução de Luiz Felipe Baeta Neves, -7ed. Rio de Janeiro: Forense Universitária, 2008.

FOUCUALT, Michel. A ordem do discurso. Loyola, São Paulo, Brasil, 1996.

GUIUMBELLI, Emerson. A presença do religioso no espaço público: modalidades no Brasil. Relig. soc. vol.28 no.2 Rio de Janeiro 2008. Disponível em < https://www.scielo.br/scielo.php?script=sci arttext\&pid=S0100-85872008000200005 >

Acessado em 24 de abril de 2019.

GUIUMBELLI, Emerson. Heresia, doença, crime ou religião: o Espiritismo no discurso de médicos e cientistas sociais. Rev. Antropol. vol.40 n.2. São Paulo. 1997. Disponível em < https://www.scielo.br/scielo.php?pid=S0034-

$\underline{77011997000200002 \& \text { script }=\text { sci arttext\&tlng }=p t}>$ Acessado em 10 de janeiro de 2019.

HERVIEU-LÉGER, Danièle. O Peregrino e o Convertido: A Religião em Movimento. Editora Vozes. 2008.

KARDEC, Allan. O Que é o Espiritismo. S/d. Sitio eletrônico. < https://kardecpedia.com/roteiro-de-estudos/885/o-que-e-o-espiritismo/1169/preambulo $>$ Acessado em 01 de julho de 2020.

LEWGOY, Bernardo. A transnacionalização do espiritismo kardecista brasileiro: uma discussão inicia. Relig. soc. vol.28 no.1. Rio de Janeiro July 2008. Disponível em < $\underline{\text { https://www.scielo.br/scielo.php?script }=\text { sci arttext\&pid }=S 0100-85872008000100005}$ >

Acessado em 20 de maio de 2019.

LEWGOY, Bernardo. Chico Xavier e a Cultura Brasileira. Rev. Antropol. vol.44 no.1. São Paulo 2001. Disponível em $<\quad$ https://www.scielo.br/scielo.php?pid=s0034-

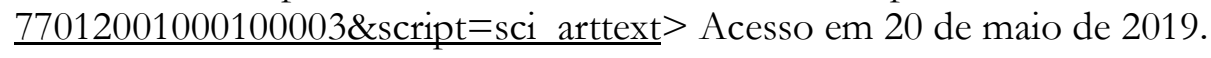

LEWGOY, Bernardo. Etnografia da leitura num grupo de estudos espírita. Horiz. antropol. vol.10 no.22 Porto Alegre July/Dec. 2004. Disponível em < https://www.scielo.br/scielo.php?pid=S0104-71832004000200011\&script=sci arttext $>$ Acesso em 20 de maio de 2019.

MESLIN, Michel. Fundamentos de antropologia religiosa: A experiência humana do divino. Editora Vozes. 2014.

MOUTINHO, Laura. Homossexualidade, Cor e Religiosidade: Flerte Entre o "Povo de Santo" no Rio de Janeiro. in Sexualidade, Família e Ethos Religioso. Garamond Editora. 2005.

PEREIRA, Francisco Jomário. "TRANSAR PODE, MAS VOCÊ NÃO DEVERIA": A Representação da Homossexualidade no Discurso Espírita Brasileiro. Tese de Doutorado em Sociologia- Universidade Federal da Paraíba. João Pessoa. 2020.

PIERUCCIR, Atônio Flávio. MARIANO, Ricardo. 2010. Sociologia da Religião, uma sociologia da mudança. In ANPOCS. São Paulo. BARCAROLLA.

SANCHIS, P. As religiões dos brasileiros. HORIZONTE - Revista de Estudos de Teologia e Ciências da Religião, v. 1, n. 2, p. 28-43, 1 ago. 1997. Disponível em < 
http://periodicos.pucminas.br/index.php/horizonte/article/view/412> Acessado em 30 de janeiro de 2020.

STOLL, Sandra Jacqueline. O Espiritismo na Encruzilhada: mediunidade com fins lucrativos?: in REVISTA USP, São Paulo, n.67, p. 176-185, setembro/novembro 2005.

STOLL, Sandra Jacqueline. Narrativas biográficas: a construção da identidade espírita no Brasil e sua fragmentação. IN ESTUDOSAVANÇADOS 18 (52), 2004.

STOLL, Sandra Jacqueline. Religião, ciência ou auto- ajuda? Trajetos do Espiritismo no Brasil. Rev. Antropol. vol.45 no.2 São Paulo 2002. 